\title{
Extolling Blackness: The African Culture in The Color Purple
}

\author{
Lei $\operatorname{Sun}^{1}$ \\ ${ }^{1}$ Foreign Languages College, Tianjin Normal University, Tianjin, China \\ Correspondence: Lei Sun, Foreign Languages College, Tianjin Normal University, Tianjin, China. E-mail: \\ Karensun123@hotmail.com
}

Received: December 4, 2016 Accepted: December 28, 2016 Online Published: January 20, 2017

doi:10.5539/ells.v7n1p13 URL: http://dx.doi.org/10.5539/ells.v7n1p13

\begin{abstract}
Alice Walker, advocates African cultures in her epistolary novel The Color Purple. Underscoring the fact that quilt-making has an ancient history in the black community and presents the African tradition of folk art and the rich legacy of visual images in African culture, Walker employs the image of quilts and quilt-making to associate with the symbolic meaning of sisterhood, family history and self-creation. Also, she depicts Shug as the most popular character as a blues singer in the novel, to indicate that she acknowledges her mode of thinking that blues as one secular African tradition can deliver its spiritual power to African Americans.
\end{abstract}

Keywords: quilt-making, blues, African culture, symbol

\section{Introduction}

Alice Walker, an African American writer, has been endowed with a strong sense of being a black in America. Born in Georgia, to black sharecropper parents, she has been endowed with a strong sense of black identity in America, which affects her subsequent involvement in Civil Rights Movement and her overt assertion of Womanism in In Search of Our Mothers' Garden. She has realized that African Americans, as outsiders and marginal people in the Anglo-Saxon white society, have been deprived of powers to dominate the American white culture. Thus, she resorts to her ethnic group for cultural expressions, exploring African cultures and traditions. It is acknowledged that Walker regarded Zora Neale Hurston as her literary mother. She has affirmed that no book means more to her than Their Eyes Were Watching God, in which Zora explores orality, one of the distinctive features in African American literary tradition, to shape an initiation story of an African American woman. Henry Louis Gates, Jr. has commented in his The Signifying Monkey that Hurston and Walker "are a tradition-within-the tradition" (Gates, 1988, p. 190). Additionally, she explores the issue of Womanism trying to reassess the world and women with an approach to African cultures. Thus, the fact that she acknowledges her love for African cultures from which derives her own artistic inspiration, reveals a strong sense of Africa-orientation.

The epistolary novel The Color Purple won Alice Walker both the American Book Award and the Pulitzer Prize in 1983. By extolling the power adopted from elements of Africa cultures, quilts and quilt-making and the blues, Walker bestows Celie and other disadvantaged black women with the wholeness of their beings.

\section{Quilts and Quilt-Making}

In In Search of Our Mother's Gardens, Walker (1983) illustrates a quilt made by “an anonymous Black woman in Alabama, a hundred years ago" (p. 239), to demonstrate the talent of creativeness of African women. "Though it follows no known pattern of quilt-making, and though it is made of bits and pieces of worthless tags," as Walker (1983) points, "it is obviously the work of a person of powerful imagination and deep spiritual feeling." (p. 239) Quilt-making, in Walker's eyes, has been one of the important symbols of African women's traits of creativity and of the source of their spiritual power. Associated with the retrospection to the history of African women over two hundred years ago, Walker (1983) extols the creativity of African American women on the assumption that "there was just such a mother..." (p. 243) in Africa.

Quilts and quilt-making have a long history in the black community, which are associated with African past, an embroidery reminiscent of the work of the Fon people of Dahomey, the former name of Benin. Since slavery time, African American women have been versed in the manufacture of worn-out pieces of clothes, quilt-making. Both the product and the process provide an outlet for thwarted energies, record a family's history by incorporating its discarded garments, and effect a reconciliation between respective characters. Even more 
importantly, quilt-making has embodied the ideal of solidarity in diversity, which permeates Walker's writings. The pieces of a quilt, like individuals in a society, retain their original identities while functioning as parts of the whole. Hence, Walker associates quilt-making with a symbolic meaning of sisterhood, family history and self-creation.

Firstly, in quilting life of African American women, the sense of sisterhood can be embodied by a "quilting bee", which usually is a quilting party, functioning for black women as a solidarity for cohesion and identity. Thus, it is probable that Walker derives the concept of sisterhood from the quilting bee to employ into her novel. In The Color Purple, the first scene where Walker mentions about quilt-making is that Celie and Sofia work together with Shug's old yellow dress. Celie entitles the quilt pattern with "Sister's Choice" (Walker, 1983, p. 62). The process of quilt-making resembles the sisterhood among Celie, Sofia and Shug. Promoting the concept of self-reliance and self-help, they sustain hope and provide survival strategies. Quilts are made with distinctive discarded scraps, reflecting the unity with diversity of ideas and inspirations; just like Celie, Sofia and Shug assimilate into a wholeness, which possess their respective traits of African American women. The process that these three black women assist one another to resist racial and patriarchal oppressions, assimilates to that of quilt-making. Only by unifying the different scraps can they create a new quilt, while only by unifying each African American woman's strength and talent sisterhood can be retained. Underscoring "African-American women recycled cloth as a means of survival" (Cash, 1995, p. 30), Shug, Sofia and Celie gain their physical and spiritual survivals respectively with sisterhood. With the stimulation and the encouragement from Shug and Sofia, Celie makes her assertion of being independent physically and spiritually in the white patriarchal society. Without Celie's affectionate tendance, Shug cannot regain her physical revival, when she falls ill. Without the close attachment among Celie, Shug and other women, it is probable that Sofia who beats down the white Mayor undergoes more painfully in prison. Thus, African American women weave resistance to double oppressions, into their daily lives of sisterhood in the black community. They create a cultural form of sisterhood that transcend their disparate experiences to invent a world of their own. Walker proposes quilt-making as an approach to sisterhood, which she identifies as the most significant source of the container for double oppressions.

Secondly, quilt-making, in Walker's eyes, symbolizes family past threading the historical and cultural experiences of family members in African American community. In the novel, when Corrine suspects that Adam and Olivia are the children of Nettie's, the most effective way for Nettie to identify is to find the quilt as a proof. In Olinka, Corrine uses the outgrown clothes and some of her old clothes to make quilts because of her appreciation of the style of the quilts. The quilts, from Nettie's tone, are "beautiful" and "full of animals and birds and people" (Walker, 1983, p. 170). From the quilts, there are some pieces of the dress Olivia wore when she was with Celie, her biological mother. The sight of "this checkered bird" triggers Corrine to recall the family history of Adam and Olivia. Thus, the quilt functions as the most distinct way to retrospect to one's family past, to establish personal identity.

Also, Walker echoes the historical connotation of quilts in her "Everyday Use", which tells a story about the quilt and African heritage among mother and her two different daughters, Maggie and Wangero. "The quilt that Wangero covets links her generation to prior generations," as David Cowart (1999) notes, "and thus they represent the larger African American past" (p. 23). Mentions should be made that the quilt covers scraps of dresses of Wangero and Maggie's grandmother and even of their great-grandmother, as well as a piece of the uniform worn by their great-grandfather who served in the Union Army in the Civil War. With the symbolic meaning of family past, Walker imposes on quilt-making, Wangero, hence, bears a sense of "deracination" (Cowart, 1999, p. 21) from her family root and history. In a word, either in The Color Purple, or in "Everyday Use", Walker employs the symbolism of quilts to retrospect to African Americans' family past. Quilts-making, as one of the traditional African customs, is delineated as an indispensable African heritage passed generation by generation.

Thirdly, quilt-making delivers a sense of self-creation and consummation. In In Search of Our Mothers' Garden, Walker (1983) highlights the creativity of black women, by declaring "They were Creators, who lived lives of spiritual waste, because they were so rich in spirituality..." (p. 233). Thus, quilt-making by black women has been endowed with a sense of creation. Besides their creation in quilts, black women create themselves. Echoing the process of quilt-making that some discarded pieces of clothes are created by those who scrabble them up, African American women reject and discard their enduring physical and spiritual experience to create a new consummate self. The abused, docile, marginal Celie ultimately realizes that "I'm [she's] pore, I'm [she's] black, I [she] may be ugly and can't cook, a voice say to everything listening. But I'm [she's] here." (Walker, 1983, p. 187). The fact that she is speaking in Godlike voice, indicates she has become a creator for herself. Rather than 
being created by the white God or the black man, she creates herself as an independent African American woman entirely. Thus, quilt-making, in Walker's eyes, has engendered a sense of self-creation by unifying the disintegrated pieces of rags into a new wholeness.

\section{The Blues and the Popular Blues Singer}

Shug Avery, a blues singer, makes a great deal of money from her performances in the novel, giving voice to the voiceless, power to the powerless. She is a woman who awakens the brutalized and silenced Celie to her own strength and sexuality. She is loved by both Albert and Celie, and is the first person to ever love Celie after Nettie leaves. Celie's quest for independence begins when Shug enters her life. She also helps Celie set up her pant business. Walker has, intentionally, imposed a symbolic meaning of blues on Shug, that is, she is "the moral center" (Bell, 1989, p. 263) in the novel.

Then, how does blues play the symbolic meaning on Shug to strengthen her popularity among African American males and females? Blues, as a form of typical African secular songs, implies an underlying strain of melancholy and self-pity. It embodies the characteristics of Africans, expressing their intention to sublimate their feelings of subjugation to achieve their own world. Blues, to some extent, signifies the pristine distillate of African culture - the spiritual strength to assert one's identity, and the resolution of arranging a sense of order in the community. African American writer Ralph Ellison defines blues as "....an impulse to deep the painful details and episodes of a brutal experience alive in one's aching consciousness, ...by squeezing from it a near-tragic, near-comic lyricism" (as quoted by Bell,1989. p. 26), highlighting the blues as a form of African American cultural self-expression.

In The Color Purple, Walker attempts to underscore the spiritual strength from blues to celebrate the lives of female blues singer, then, to reveal the reason why Shug enjoys popularity in her community. "...with the blues," Walker once illustrates her belief in the spiritual power of blues, "you feel like you are hearing authentic feeling and that people are struggling to find joy in life" (as quoted by Ferris, 2004, p. 23). Shug is favored by everyone, no matters the male or the female. Mr. _ and other men are in fascination with her; meanwhile, Celie, Sofia and other women are enchanted by her voice and her distinctive character. As a blues singer, she is entitled with an honorific title "Queen Honeybee". Why is she so favored by public? Let's scrutinize Mr.__'s frank acknowledgement of his love for Shug to his wife Celie:

Mr.__ ast me the other day what it is I love so much bout Shug. He say he love her style. He say to tell the truth, Shug act more manly than most men. I mean she upright, honest. Speak her mind and the devil take the hindmost, he say. You know Shug will fight, he says. Just like Sofia. She bound to live her life and be herself no matter what (Walker, 1983, p. 236).

Shug's "style", exactly speaking, the "style" of her loyalty to pursuing independence honestly and straight forwardly, is her charm to men and women. Wang (2001) explains that Shug's popularity "connotes the worship of black people and their admiration for black traditional culture" (p. 33).

In the novel, Walker bestows the blues singer with spiritual strength of blues to assert her identity as wholeness, either spiritually or materially. She creates herself and becomes the owner of herself. Although she couldn't marry Mr. _ , she clutches his heart firmly. And she shows her love regardless of traditional gender roles in the community: she married several times overlooking the strong restriction to a black woman; the last husband Grady is much younger than her. When Shug sings in the bar, not only black men, but also black women, including Sofia, are attracted to her songs. The reason why she is extremely charming to black men and women, probably is, that Shug is an excellent blues singer who embodies the spiritual strength to assert her identity and to pursue her independence.

Meanwhile, Walker endows this catalyst-like blues singer with a backbone role in creating a sense of order in the community. "Shug, like Bessie Smith," Marvin (1994) elaborates the effect of blues singers' singing, "forges a strong bond with her audiences and gives voice to the "spirit of the blues" in order to bring relief to less articulate sufferers." (p. 411) Also, he explains charms of blues singer from the perspective of anthropology, that is, Shug can be considered a follower of Legba, a West African spirit closely associated with musicians, who opens the door to the spiritual world and offers opportunities for the social and psychological growth of the individual. The blues "queen" is a "honeybee", who arranges hive-like order at the end of the novel, leading both men and women to live harmoniously in the new order. In other words, she crosses the social boundaries that often restricted the women of her society, making possible the gender role reversals to challenge the patriarchal society. Her blues spirit of vitality, flexibility, and creativity, not only endures staunchly, but also flourishes potentially. Thus, Shug's blues songs serve as sacred lyrical expressions of tough times, and as a spiritual inspiration of overcoming personal difficulties. 
The blues singer empowers those who love her and leads metamorphosis to those around her. She is crucial to helping Celie find love and the ability to leave sexual-abusing Albert. Actually, she is the mother-like (Note 1) guide in the Celie's journey to spiritual, sexual and material awakening. Just like blues is able to release thwarted accumulated melancholy of listeners, Shug, the blues singer also helps Celie break through the accumulated pain of her previous torturous experiences by modifying her mode of thinking and by offering her love. She teaches Celie not only the importance of enjoying her sexual affairs, such as drawing Celie's attention of her "little button" and "finger and tongue work", but also about the spiritual independence converting a white Christian God into an animistic one. Following Shug, Celie's increasing self-reliance leaves her little need or inclination to continue her relationship with the Christian God of her earlier and more vulnerable days. Shug transforms the life of Celie, bringing about a "blues conversion" (Marvin, 1994, p. 411) that allows her to take charge of her own destiny. Materially, she also helps Celie set up her pant business. She helps Celie to recognize that her talent for making pants could be turned into a business, pointing her the way to financial independence, which makes it possible for them to leave Mr. and establish a new life in Memphis. Mr._ is also transformed from an abusing, patriarchal, careless black man, into "the only one understand my [Celie's] feeling" (Walker, 1983, p. 229), working alongside with Celie in the pant business. Thus, the ending is really the beginning for Celie. Living the liberated life as she sings, Shug, like Bessie, imperceptibly challenged Mr.__, Celie and readers to live with braveness in face of conventional morality. What's more, Shug also liberates "Squeak" Mary Agnes, a quiet, submissive woman, by encouraging her to sing blues. Finally, Mary has reclaimed the right to assert her own identity by insisting Harpo to call her "Mary Agnes" instead of "Squeak", and to sing her own blues empowered by Shug's blues. In a word, most of the black women have asserted their own identities catalysed by the spiritual power associated with blues. And the black patriarchal community has been challenged, then, arranged with a sense of new order by the blues singer.

In her portraits of the blues singer, Walker shows us the spirit of vitality, flexibility, and creativity of African American women, illuminating the spiritual strength from blues to assert one's identity, and to arrange a sense of order in life. Indeed, the blues female singer, Shug, exhibits her blues performances with vitality and aliveness. Shug, bestowed with the spiritual power of blues, is portrayed as a womanist of inner strength, generosity, resistance, confidence, and love of everything.

\section{Conclusion}

In a word, Alice Walker has employed the symbolism of African traditions and cultures to depict Celie's triumph of her struggles against racism and sexism, ultimately into the wholessness of her being. Bestowed with the symbolic meaning of sisterhood, family history and self-creation from African quilts and quilt-making, Walker portrays a successful initiation story of Celie. Furthermore, the blues, in the novel, has been interpreted as the spiritual strength to assert one's identity, and as the resolution of arranging a sense of order in the community, to help Celie to be independent.

\section{References}

Bell, B. W. (1989). The Afro-American Novel and Its Tradition. Amherst, MA: U of Massachusetts Press.

Cash, F. B. (1995). Kinship and Quilting: An Examination of an African-American Tradition. The Journal of Negro History, 80(1), 30-42. https://doi.org/10.2307/2717705

Cowart, D. (1999). Heritage and Deracination in Walker's "Everyday Use. In Dieke (Ed.), Critical Essays on Alice Walker (pp. 21-32). Westport, CT: Greenwood Press.

Ferris, W. R. (2004). Alice Walker: "I know what the earth says". Southern Cultures, 10(1), (Spring), 5-24. https://doi.org/10.1353/scu.2004.0004

Gates, H. L. Jr. (1988). The Signifying Monkey: A Theory of Afro-American Literary Criticism. New York and Oxford: Oxford U Press.

Marvin, T. F. (1994). Preachin' the Blues: Bessie Smith's Secular Religion and Alice Walker's "The Color Purple". African American Review, 28, 411-423. https://doi.org/10.2307/3041977

Walker, A. (1983). In Search of our Mothers' Gardens. San Diego: New York; London: Harcourt, Brace, Jovanovich.

Walker, A. (1983). The Color Purple. New York: Harcourt, Brace, Jovanovich.

Wang, C. (2001). The Color Purple and Alice Walker's Eurocentrism. Foreign Literature Studies, 4, 30-36. 


\section{Note}

Note 1. In the article “'Preachin' the Blues': Bessie Smith's Secular Religion and Alice Walker's 'The Color Purple", Marvin has surmurized the role of Shug to Celie from different perspectives: a "fairy godmother" to Celie in terms of a "fairy tale"; a "nurse", a "mother-imago", a "mother surrogate" for Celie in terms of psychoanalytic criticism.

\section{Copyrights}

Copyright for this article is retained by the author(s), with first publication rights granted to the journal.

This is an open-access article distributed under the terms and conditions of the Creative Commons Attribution license (http://creativecommons.org/licenses/by/4.0/). 